UDC 502.174:504.5

582.681.81:669.018.674

Original research paper

doi: 10.5937/AASer1846167D

Acta Agriculturae Serbica, Vol. XXIII, 46 (2018); 167-176

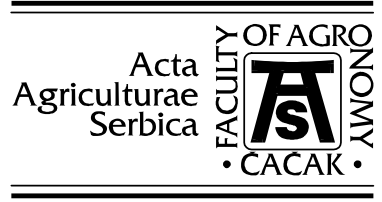

\title{
Uptake and distribution of metals in Populus nigra and Populus tremula
}

\author{
Gorica Đelić ${ }^{1}$, Siniša Timotijević ${ }^{1}$, Zoran Simić ${ }^{2}$ \\ ${ }^{1}$ University of Kragujevac, Faculty of Science, Department of Biology and \\ Ecology, Kragujevac, Serbia \\ ${ }^{2}$ University of Kragujevac, Faculty of Science, Department of Chemistry, \\ Kragujevac, Serbia \\ *Corresponding author: sinisatimotijevic@gmail.com
}

\begin{abstract}
Woody plants are increasingly used in the remediation of contaminated land. The content of metals ( $\mathrm{Mn}, \mathrm{Fe}, \mathrm{Cu}, \mathrm{Zn}, \mathrm{Cr}, \mathrm{Ca}, \mathrm{Mg}$ ) was analyzed in the plant species Populus nigra L. and Populus tremula L. and in the soil on which they grow. The aim of the research was to determine differences between these two species based on the content of metals in plant organs (sprouts and leaves) and bioaccumulation potential and point out the potential application of these species in phytoremediation. Atomic absorption spectrometry was used to measure these heavy metals in soil and plant material. The results showed that $P$. tremula was a better metal accumulator because it absorbed larger quantities of $\mathrm{Mn}, \mathrm{Fe}, \mathrm{Cu}$ and $\mathrm{Zn}$ from $P$. nigra. $P$. nigra absorbed more chromium than $P$. tremula. Both species proved to be good zinc accumulators, and better bioaccumulation potential was found in $P$. tremula of $P$. nigra, although aspen had a strong negative correlation with Zn.
\end{abstract}

Keywords: $P$. nigra L., P. tremula L., phytoremediation, metals

\section{Introduction}

The presence of metals/metalloids in toxic amounts is a particularly important ecological problem unfavorably affecting human health. Metals in the soil are primarily derived from the geological substrate (Langer 2011).

Received 29 June 2018 Accepted 22 September 2018 
In higher concentrations, $\mathrm{Zn}$ is phytotoxic; therefore, studying this metal is very important because it directly affects soil fertility, and the yield, and quality of cultivated plants. The main sources of soil pollution with $\mathrm{Zn}$ are: pesticides, fertilizers, mines, iron foundries, use of waste sludges in agriculture, composted materials (Kiekens et al., 1995). A high concentration of $\mathrm{Zn}$ is toxic to plants. There are plant species that have a distinct ability to accumulate $\mathrm{Zn}$. In such plants, the $\mathrm{Zn}$ content in the whole biomass can range from 1.6 to $17 \%$ (Kastori, 1997).

Plants that have the ability to absorb large amounts of heavy elements are used in phytoremediation processes. Perennial woody plants are increasingly used to remove metals from soil and transfer them into harmless forms (Miller et al., 2011). Plants of the fam. Salicaceae are increasingly used in phytoremediation technologies (Isebrands and Karnosky, 2001) because they are tolerant to floods, rapidly growing and spreading easily, can grow from cuttings, have the ability to tolerate many types of toxic substances (both inorganic and organic compounds) (Schnoor, 1997).

Poplars (Populus) are resistant to the presence of metal (Cd, Cu, $\mathrm{Zn}, \mathrm{Ni}, \mathrm{Pb}$, $\mathrm{Fe}$ ) and have the ability to accumulate significant amounts of these pollutants in the plant. As documented and suggested in many papers, the use of these plants is very profitable and cost-effective in the extraction of metals from contaminated environments (Schnoor, 1997; Keller et al., 2003; Pietrosanti et al., 2004).

The aim of this study was to investigate the potential of $P$. nigra L. and $P$. tremula L., growing on unpolluted soils, for phytoextraction of selected elements and the possibility to use these plants for decontamination of areas polluted with $\mathrm{Ca}, \mathrm{Cd}, \mathrm{Co}, \mathrm{Cr}, \mathrm{Cu}, \mathrm{Fe}, \mathrm{Mg}, \mathrm{Mn}, \mathrm{Ni}, \mathrm{Pb}, \mathrm{Zn}$. Additionally, the research examined the content and relationship of essential plant elements $\mathrm{Ca}$ and $\mathrm{Mg}$ in plants and land.

\section{Material and methods}

Branches with leaves of $P$. nigra L. (black poplar) and P. tremula L. (aspen) were collected for the analysis of the concentration and distribution of metals $\mathrm{Ca}, \mathrm{Cd}, \mathrm{Co}, \mathrm{Cr}, \mathrm{Cu}, \mathrm{Fe}, \mathrm{Mg}, \mathrm{Mn}, \mathrm{Ni}, \mathrm{Pb}$ and $\mathrm{Zn}$. P. tremula plant material and soil were collected from the Trešnjevica village site (43.135235"N, 19.872544"E) (25 km southwest of Sjenica). P. nigra plant material and soil were collected from the Ovčar spa.

Samples of plants, twigs, and leaves were harvested in August and October 2015. After collection, leaves were dried. The plant material was milled. Plant material was digested with concentrated $\mathrm{HNO}_{3}$ and $\mathrm{HClO}_{4}$. Soil samples were generally taken from a depth of $0-10 \mathrm{~cm}$ after removing any loose organic matter from the surface. The soils were air-dried and sieved initially to $<2 \mathrm{~mm}$ to remove any stony material. Soil samples were prepared by standard procedure 
(using $\mathrm{HCl}$ ) for the preparation of samples for chemical analysis (APHA AWWA WPCF 1998).

In the soil and plants samples, the concentrations of $\mathrm{Ca}, \mathrm{Mg}, \mathrm{Fe}, \mathrm{Mn}, \mathrm{Zn}, \mathrm{Cr}$, $\mathrm{Ni}, \mathrm{Pb}, \mathrm{Co}$ and Cd were determined using a Perkin Elmer Analyst 3300 flame atomic absorption spectrometer at the Faculty of Science in Kragujevac. Each sample was analyzed in six repetitions, followed by calculation of mean value and standard deviation.

A bioaccumulation factor was also calculated. Metal concentration in the plant material and the soil was expressed in mg/kg of dry matter (d.m).

It takes time for plants to reduce the amount of heavy metals in contaminated soils depending on the production of biomass and the bioaccumulation coefficient. The bioaccumulation coefficient is obtained using the next formula:

BAF=Cplantmaterial/Csoil

Cplantmaterial and Csoil are metal concentrations in the plant material $\left(\mathrm{mgkg}^{-1}\right)$ and soil (mgkg ${ }^{-1}$ ), respectively (Kabata-Pendias, 2011).

The differences in the concentrations of metals in the plants, and between the plants and the soil were determined by the analysis of variance (one-way ANOVA) at the level of significance of $\mathrm{p}<0.05$. Statistical significance was also determined using Pearson's correlation coefficient. It was determined whether there was a statistically significant difference in the content of metals between soil and plants. The correlation coefficient (r) was measured as: 0-0.3: no correlation; 0.3-0.5: poor correlation; 0.5-0.7: medium correlation; 0.7-0.9: high correlation: 0.9-1.0: very high statistically significant correlation (Ward, 1963; Brereton, 2003; Temple et al., 2006). Statistical analysis was performed using the SPSS Statistics software (SPSS 16 for Windows).

\section{Results}

The results of the analysis of metal concentrations (Ca, Cd, Co, Cr, $\mathrm{Cu}, \mathrm{Fe}$, $\mathrm{Mg}, \mathrm{Mn}, \mathrm{Ni}, \mathrm{Pb}, \mathrm{Zn}$ ) in the soil from which the plant material was collected is shown in Table 1. The amount of $\mathrm{Cd}$ in the soil was below the detection limit.

In all tested soils, Fe predominated, whereas the amount of Co was the lowest.

The results of the analysis of metal concentrations (Ca, Cd, Co, Cr, $\mathrm{Cu}, \mathrm{Fe}$, $\mathrm{Mg}, \mathrm{Mn}, \mathrm{Ni}, \mathrm{Pb}, \mathrm{Zn}$ ) in the leaf and twig samples of the studied species are shown in Table 2. The concentrations of $\mathrm{Ni}, \mathrm{Pb}, \mathrm{Co}$ and $\mathrm{Cd}$ in plant parts were below the detection limit. 
Table 1. The concentration [mg kg-1 d.m] of Ca, Cd, Co, Cr, Cu, Fe, Mg, Mn, Ni, $\mathrm{Pb}$ and $\mathrm{Zn}$ in the tested soil

\begin{tabular}{cccc}
\hline \multirow{2}{*}{ metal } & $\begin{array}{c}\text { Populus } \\
\text { tremula }\end{array}$ & $\begin{array}{c}\text { Populus } \\
\text { nigra }\end{array}$ & \multirow{2}{*}{ MPC } \\
\cline { 2 - 3 } & Soil & Soil & \\
\hline $\mathbf{M n}$ & $495.5 \pm 5.17$ & $288.8 \pm 2.35$ & 2000 \\
\hline $\mathbf{F e}$ & $19436.7 \pm 39.43$ & $37760.8 \pm 39.0$ & 50000 \\
\hline $\mathbf{C u}$ & $16.5 \pm 0.46$ & $26.9 \pm 0.42$ & 100 \\
\hline $\mathbf{Z n}$ & $46.8 \pm 0.55$ & $49.8 \pm 0.64$ & 300 \\
\hline $\mathbf{C r}$ & $305.5 \pm 1.93$ & $505.0 \pm 5.55$ & 100 \\
\hline $\mathbf{C a}$ & $6630.5 \pm 34.67$ & $8054.3 \pm 35.71$ & \\
\hline $\mathbf{M g}$ & $3054.7 \pm 26.23$ & $28041 \pm 32.41$ & \\
\hline $\mathbf{N i}$ & $9.4 \pm 0.03$ & $89.5 \pm 0.69$ & 50 \\
\hline $\mathbf{P b}$ & $24.2 \pm 0.77$ & $29.9 \pm 0.34$ & \\
\hline $\mathbf{C o}$ & $7.1 \pm 0.08$ & $20.8 \pm 0.60$ & \\
\hline $\mathbf{C d}$ & $\mathrm{ND}$ & $\mathrm{ND}$ & \\
\hline
\end{tabular}

Table 2. The concentration [mg kg-1 d.m] of Ca, Cd, Co, Cr, Cu, Fe, Mg, Mn, Ni, $\mathrm{Pb}$ and $\mathrm{Zn}$ in the twigs and leaves of the studied plants species

\begin{tabular}{ccccc}
\hline \multirow{2}{*}{ metal } & P. tremula & P. nigra & P. tremula & P. nigra \\
\cline { 2 - 5 } & Leaf & Leaf & Twigs & Twigs \\
\hline $\mathbf{M n}$ & $75.7 \pm 0.36$ & $52.5 \pm 1.1$ & $456.6 \pm 0.78$ & $16.6 \pm 0.42$ \\
\hline Fe & $418.3 \pm 0.69$ & $300.4 \pm 1.6$ & $294.5 \pm 0.93$ & $318.9 \pm 0.66$ \\
\hline $\mathbf{C u}$ & $4.6 \pm 0.07$ & $4.5 \pm 0.06$ & $12.5 \pm 0.28$ & $6.2 \pm 0.80$ \\
\hline $\mathbf{Z n}$ & $64.8 \pm 0.44$ & $70.8 \pm 0.32$ & $117.0 \pm 0.57$ & $27.9 \pm 0.52$ \\
\hline $\mathbf{C r}$ & $20.8 \pm 0.67$ & $16.4 \pm 0.44$ & $20.1 \pm 0.58$ & $40.4 \pm 0.17$ \\
\hline $\mathbf{C a}$ & $10967.3 \pm 55.52$ & $46542.3 \pm 171.41$ & $27181.5 \pm 78.52$ & $11896.5 \pm 77.35$ \\
\hline $\mathbf{M g}$ & $1567.0 \pm 23.96$ & $9570 \pm 17.69$ & $3475.2 \pm 138.84$ & $1591.3 \pm 10.42$ \\
\hline
\end{tabular}

The mean values of the metal concentrations in branch samples of $P$. tremula were $\mathrm{Ca}>\mathrm{Mg}>\mathrm{Mn}>\mathrm{Fe}>\mathrm{Zn}>\mathrm{Cr}>\mathrm{Cu}$, while those in $P$. nigra branches followed the order: $\mathrm{Ca}>\mathrm{Mg}>\mathrm{Fe}>\mathrm{Cr}>\mathrm{Zn}>\mathrm{Mn}>\mathrm{Cu}$. 
The mean values of the metal concentrations in the leaves of $P$. nigra were ordered as follows: $\mathrm{Ca}>\mathrm{Mg}>\mathrm{Fe}>\mathrm{Zn}>\mathrm{Mn}>\mathrm{Cr}>\mathrm{Cu}$. In the leaves of $P$. tremula the mean values of the metal concentrations followed the order: $\mathrm{Ca}>\mathrm{Mg}>\mathrm{Fe}>$ $\mathrm{Mn}>\mathrm{Zn}>\mathrm{Cr}>\mathrm{Cu}$.

The results of the analysis of the bioaccumulation coefficients for the tested metals are shown in Table 3.

Twigs of $P$. nigra and $P$. tremula had bioaccumulation coefficients greater than 1 for $\mathrm{Ca}$, and the bioaccumulation coefficient for $\mathrm{Zn}$ in P. tremula was larger than 1 . The smallest bioaccumulation coefficient of the branches was found for Fe.

The leaves of all investigated plants had bioaccumulation coefficients greater than 1 for $\mathrm{Ca}$ and $\mathrm{Zn}$.

Table 3. Bioconcentration factor values

\begin{tabular}{ccccc}
\hline \multirow{2}{*}{$\begin{array}{l}\text { Plant } \\
\text { org./soil }\end{array}$} & Pwigs & Twigs & Leaf & Leaf \\
\hline & Twemula & P. nigra & P. tremula & P. nigra \\
\hline $\mathrm{Mn}$ & 0.92 & 0.06 & 0.15 & 0.18 \\
\hline $\mathrm{Fe}$ & 0.01 & 0.008 & 0.02 & 0.01 \\
\hline $\mathrm{Cu}$ & 0.75 & 0.23 & 0.28 & 0.17 \\
\hline $\mathrm{Zn}$ & 2.5 & 0.56 & 1.38 & 1.42 \\
\hline $\mathrm{Cr}$ & 0.06 & 0.08 & 0.07 & 0.03 \\
\hline $\mathrm{Ca}$ & 4.1 & 1.48 & 1.65 & 5.78 \\
\hline $\mathrm{Mg}$ & 1.14 & 0.06 & 0.51 & 0.34 \\
\hline
\end{tabular}

The analysis of variance was used to compare metal concentrations in the soil and the selected plant species in various regions, to determine the ability of these plants to accumulate the test metals. The results showed statistically very significant differences in the content of metals between the selected species and soil. Also, there was a statistically significant difference in the content of the tested metals in the selected plant species, which were sampled from different locations.

The values of the coefficient of correlation between the concentrations of metals in the investigated plant species (Table 4) showed a positive correlation (0-1) for the content of chromium in twigs and leaves of $P$. nigra and $P$. tremula, and a negative correlation (-1-0) for the Ca content of the leaves of both plants and the soil. In Table 4, strong positive and negative correlations are highlighted (*). 
Table 4. The values of the coefficients of correlation (r) between the concentrations of metals in the soil and the plant species

\begin{tabular}{ccccccccc} 
& & $\mathrm{Mn}$ & $\mathrm{Fe}$ & $\mathrm{Cu}$ & $\mathrm{Zn}$ & $\mathrm{Cr}$ & $\mathrm{Ca}$ & $\mathrm{Mg}$ \\
\hline $\begin{array}{c}\text { Plant } \\
\text { species }\end{array}$ & $\begin{array}{c}\text { Plant } \\
\text { organ }\end{array}$ & $\mathrm{R}$ & $\mathrm{R}$ & $\mathrm{R}$ & $\mathrm{R}$ & $\mathrm{R}$ & $\mathrm{R}$ & $\mathrm{R}$ \\
\hline $\begin{array}{c}P . \\
\text { nigra }\end{array}$ & Twigs & -0.46 & -0.37 & -0.03 & 0.37 & 0.20 & 0.22 & -0.68 \\
\hline $\begin{array}{c}P . \\
\text { tremula }\end{array}$ & Teaf & 0.17 & -0.42 & 0.15 & 0.17 & $0.85^{*}$ & -0.43 & -0.12 \\
\hline
\end{tabular}

\section{Discussion}

The manganese content in the tested soils was below exposure limits (495.5 and $288.8 \mathrm{mg} / \mathrm{kg}$, respectively). P. tremula accumulated more manganese (75.7 and $456.6 \mathrm{mg} / \mathrm{kg}$, respectively) compared to $P$. nigra (52.5 and $16.6 \mathrm{mg} / \mathrm{kg}$, respectively). The amount of manganese found in $P$. tremula (Table 2) was above the lower limit of manganese toxicity $(80 \mathrm{mg} / \mathrm{kg})$ according to Le Bot et al. (1996), which indicates that this species is tolerant to some extent.

The concentration of iron in the tested soils was below permissible levels except at the location of Čačak $(51,421 \mathrm{mg} / \mathrm{kg})$ (Table 1). The amount of iron in the examined species was within the limit values (50 to $500 \mathrm{mg} / \mathrm{kg}$, KabataPendias, 2011). Leaf of $P$. tremula absorbed higher Fe concentrations (418.3 $\mathrm{mg} / \mathrm{kg}$ ) compared to $P$. nigra (300.4 mg/kg), while $P$. nigra twig absorbed higher Fe concentrations (318.9 mg/kg) compared to $P$. tremula twig $(294.5 \mathrm{mg} / \mathrm{kg})$.

The amount of copper in the analyzed soil was lower than the average value (16.5 mg/kg and $26.9 \mathrm{mg} / \mathrm{kg}$, respectively) (Table 1) according to KabataPendias (2011) (about $30 \mathrm{mg} / \mathrm{kg}$ ). Research results (Table 2) showed that the test species absorbed a small amount of copper (Greater concentrations of copper in the leaves and twigs were uptaken by aspen (4.6 and $12.5 \mathrm{mg} / \mathrm{kg}$, respectively) than by black poplar (4.5 and $6.2 \mathrm{mg} / \mathrm{kg}$, respectively).

The analysis of the chromium content in the soil from which the plant material was taken showed that the soil contained 3 to 5 times higher concentrations than the maximum allowed quantity (Table 1). Our results showed much higher chromium concentrations than average values $(0.1-0.4 \mathrm{mg} / \mathrm{kg})$ in twigs and leaves (Table 2) of the investigated plants (Salt et al., 1999), which indicates that the tested types were tolerant of this metal, but are not good accumulators, given their low bioaccumulation coefficients. $P$. tremula leaf accumulated more chromium $(20.8 \mathrm{mg} / \mathrm{kg}$ ) compared to $P$. nigra leaf (16.4 $\mathrm{mg} / \mathrm{kg})$, while the twig of $P$. nigra accumulated twice more $\mathrm{Cr}(40.4 \mathrm{mg} / \mathrm{kg})$ compared to the twig of $P$. tremula $(20.1 \mathrm{mg} / \mathrm{kg}$ ) (Table 2). The content of $\mathrm{Cr}$ in 
P. nigra was far above the concentration recorded by Kacálková et al. (2014) (Populus nigra L. x P. maximowiczii $0.78 \mathrm{mg} / \mathrm{kg}$ in leaf).

In the soil from the Ovčar Spa site, the concentration of $\mathrm{Ca}$ was lower in relation to $\mathrm{Mg}$ and at the Trešnjevica site it was higher (Table 1). Comparison with $\mathrm{Mg}$ is given because the ratio of the amount of $\mathrm{Ca}: \mathrm{Mg}$ in the soil is important for normal plant development.

The concentration of Ca in the leaf was four times higher in P. nigra (46,542 $\mathrm{mg} / \mathrm{kg}$ ) than in $P$. tremula $(10,967 \mathrm{mg} / \mathrm{kg})$, while the concentration in twigs was $228 \%$ greater in $P$. tremula $(27,181.5 \mathrm{mg} / \mathrm{kg})$ than in $P$. nigra $(11,896.5 \mathrm{mg} / \mathrm{kg})$. Bioaccumulation coefficients in the investigated species were high (Table 3). Better bioaccumulation properties were obtained for $P$. nigra (1.48 per yield and 5.78 for leaf) than for $P$. tremula (4.1 for sprouting and 1.65 for leaf).

The uptake of magnesium by $P$. nigra leaf was 6 times higher $(9570 \mathrm{mg} / \mathrm{kg})$ than that of $P$. tremula $(1567 \mathrm{mg} / \mathrm{kg}$ ), while $P$. tremula twigs absorbed $218 \%$ higher concentration of $\mathrm{Mg}(3475.2 \mathrm{mg} / \mathrm{kg}$ ) relative to $P$. nigra twigs (1591.3 $\mathrm{mg} / \mathrm{kg}$ ). Bioaccumulation coefficient was low (Table 3) (except for the twigs of P. tremula 1.14).

The content of $\mathrm{Zn}$ in the tested soil was below the MPC value (Table 1) (50 $\mathrm{mg} / \mathrm{kg}$ Ludajić, 2014). P. nigra leaf absorbed a higher concentration of Zn (70.8 $\mathrm{mg} / \mathrm{kg}$ ) compared to $P$. tremula leaf $(64.8 \mathrm{mg} / \mathrm{kg})$, while the twigs of $P$. tremula absorbed a higher concentration of $\mathrm{Zn}(117 \mathrm{mg} / \mathrm{kg})$ as compared to $P$. nigra twig $(27.9 \mathrm{mg} / \mathrm{kg})$. Both of the investigated plant species proved to be good zinc accumulators (Table 3). Bioaccumulation potential was better in P. tremula (2.5 and 1.38 ) than in P. nigra (0.56 and 1.42) although aspen had a strong negative correlation with $\mathrm{Zn}$. In this study, native poplars, grown on uncontaminated soil, showed the ability of phytoremediation.

The amount of zinc in $P$. tremula twig $(117 \mathrm{mg} / \mathrm{kg})$ was $44.6 \%$ higher than the quantity in the leaf $(64.8 \mathrm{mg} / \mathrm{kg})$ (Table 2). P. tremula that grows close to mines on contaminated soil can accumulate up to $3600 \mathrm{mg} / \mathrm{kg} \mathrm{Zn}$ and $45 \mathrm{mg} / \mathrm{kg}$ Cd in leaves (Unterbrunner et al. 2007, Krpata et al., 2009). Zn concentration in the leaf of the hybrid Populus tremula $x$ Populus tremuloides that grew on contaminated sites in the south of France was $950 \mathrm{mg} / \mathrm{kg} \mathrm{Zn} \mathrm{(Migeon} \mathrm{et} \mathrm{al.,}$ 2009). The concentration of zinc in these studies was much higher than our results because these poplars grew on contaminated soils. Bioaccumulation factor for twigs and leaves in the present study was 2.5 and 1.38, respectively (Table 3), based on which aspen can be classified into hyperaccumulator plants. Migeon et al. (2009) obtained the following coefficients for $\mathrm{Zn}$ : Populus tremula $\times$ Populus tremuloides 1.22; Populus tremula $\times$ Populus alba 0.41. Bioaccumulation coefficients in this study were lower than ours. The reason is that our poplar grew on land that was not overloaded with zinc.

In $P$. nigra leaf, the amount of zinc $(70.8 \mathrm{mg} / \mathrm{kg})$ was $60.6 \%$ higher than the amount found in the twig $(27.9 \mathrm{mg} / \mathrm{kg}$ ) (Table 2). Dos Santos Utmazian and Wenzel (2007), in experiments with willows and poplars, which were subjected 
to the combined action of $\mathrm{Cd}$ and $\mathrm{Zn}$ (plus $\mathrm{Cu}$ and $\mathrm{Pb}$ ), recorded $\mathrm{Zn}$ concentrations of 596 to $935 \mathrm{mg} / \mathrm{kg}$ in clones of P. nigra. Di Baccio et al. (2003) found that $P$. nigra plants have the potential to be used in plantations on soils loaded with zinc. Zinc concentrations in clones were considerably higher than those of the native species that we tested, but $P$. nigra has a great natural potential to uptake zinc, as shown in our research.

The bioaccumulation coefficient of zinc was 0.56 for twig and 1.42 for the leaf. Based on the bioaccumulation coefficient (Table 3) for zinc in the leaf, the species $P$. nigra can be classified into hyperaccumulator plants. The bioaccumulation coefficient was 0.62 for $P$. nigra and 0.78 for the $P$. deltoids $x$ P. nigra clone, (Migeon et al. 2009), lower than in our results.

In general, $P$. tremula proved to be a better metal accumulator because it absorbed larger amounts of $\mathrm{Mn}, \mathrm{Fe}, \mathrm{Cu}$ and $\mathrm{Zn}$ compared to P. nigra ( $P$. nigra absorbed more chromium than $P$. tremula). It is interesting to note that the twig of $P$. tremula accumulated larger amounts of $\mathrm{Mn}, \mathrm{Zn}, \mathrm{Ca}$ and $\mathrm{Mg}$ in relation to leaves, as opposed to $P$. nigra. The leaf of $P$. tremula accumulated more Fe in relation to the twigs, while the reverse situation was observed in black poplar.

\section{References}

APHA, AWWA, WPCF (1998): Standard Methods for the Examination of Water and Wastewater. American Public Health Association, Washington, DC.

Di Baccio D., Roberto T., Sebastiani L., Vitagliano C. (2003): Responses of Populus deltoids $\times$ Populus nigra (Populus $\times$ euramericana) clone I-214 to high zinc concentrations. New Phytologist, 159: 443-452.

Dos Santos Utmazian M.N., Wenzel W.W. (2007): Cadmium and zinc accumulation in willow and poplar species grown on polluted soils. Journal of Plant Nutrition and Soil Science, 170: 265- 272.

Isebrands J.G., Karnosky D.F. (2001): Environmental benefits of poplar culture. In Poplar Culture in North America, (Part A), 207-218.

Kabata-Pendias A. (2011): Trace elements in soils and plants, 4th edition, CRC Press, Taylor and Francis Group, Boca Ration, London, New York.

Kacálková L., Tlustoš P., Száková J. (2014): Chromium, nickel, cadmium, and lead accumulation in maize, sunflower, willow, and poplar. Polish Journal of Environmental Studies, 23 (3): 753-761.

Kastori R. (1997): Teški metali u životnoj sredini, Poljoprivredni fakultet i Naučni institut za ratarstvo i povrtarstvo, Novi Sad.

Keller C., Hammer D., Kayser A., Richner W., Brodbeck M., Sennhauser M. (2003): Root development and heavy metal phytoextraction efficiency: Comparison of different plant species in the field. Plant Soil, 249: 67-81.

Kiekens L., Zinc. In: B. J. Alloway (Ed.) (1995): Heavy metals in soils, Blackie Academic \& Professional, Glasgow, UK.

Krpata D., Fitz W., Peintner U., Langer I., Schweiger P. (2009): Bioconcentration of zinc and cadmium in ectomycorrhizal fungi and associated aspen trees as affected by level of pollution. Environmental Pollution, 157: 280-286. 
Langer I. (2011): Evaluation for a plant-assisted bioremediation approach: Zn (Cd) accumulation properties of indigenous poplar species and the impact of ectomycorrhizas on phytoextraction characteristics, PhD thesis, University of Natural Resources and Life Sciences, Department of Forest and Soil Sciences, Institute for Soil Science, Rhizosphere Ecology and Biogeochemistry Group. Vienna.

Le Bot J., Kirkby A.E., Van Beusichem L.M. (1996): Manganese toxicity in tomato plants. Effects on cation uptake and distribution. Journal of Plant Nutrition, 13 (5): 513-525.

Ludajić G. (2014): Uticaj blizine frekventnih saobraćajnica na sadržaj toksičnih elemenata u zemljištu i pšenici, PhD thesis, Univerzitet u Novom Sadu, Tehnološki fakultet, Novi Sad: 1-134 (in serbian).

Migeon A., Richaud P., Guinet F., Chalot M., Blaudez D. (2009): Metal Accumulation by Woody Species on Contaminated Sites in the North of France. Water Air Soil Pollut, 204: 89-101.

Miller R.S., Khan Z., Doty S.L. (2011): Comparison of trichloroethylene toxicity, removal, and degradation by varieties of Populus and Salix for improved phytoremediation applications, Journal of Bioremediation and Biodegradation, S7:001.

Pietrosanti L., Matteucci G., Pietrini F., Capotorti G., Molinari M., Magnani E., Santarelli G., Zuin M.C. (2004): Hydrological control and phytoremediation by poplar and willow clones in a contaminated industrial site in Venice lagoon, 4th European Bioremediation Conference ID 138.

Salt D.E., Kato N., Kramer U., Smith R.D., Raskin I. (1999): The role of root exudates in nickel hyperaccumulation and tolerance in accumulator and nonaccumulator species of Thlaspi, In Phytoremediation of contaminated soil and water, CRC Press, London.

Schnoor J.L. (1997): Phytoremediation. Ground-Water Remediation Technologies Analysis Center. Pittsburgh, PA 15238. TE-98-01. Technology Evaluation Report.

Temple M., Filzmoser P., Reinannn A. (2006): Cluster analysis applied to regional geochemical data: problems and possibilities. Forschungsberich, Vienna University of Technology.

Unterbrunner R., Puschenreiter M., Sommer P., Wieshammer G., Tlustos P., Zupan M., Wenzel W.W. (2007): Heavy metal accumulation in tree growing on contaminated sites in Central Europe. Environmental Pollution, 148: 107-114.

Ward J.H. (1963): Hierarchical grouping to optimize an objective function. Journal of the Americal Statistical Associatiob, 58: 236-244. 


\title{
USVAJANJE I DISTRIBUCIJA METALA U BILJNIM VRSTAMA POPULUS NIGRA I POPULUS TREMULA
}

\author{
Gorica Đelić ${ }^{1}$, Siniša Timotijević ${ }^{1}$, Zoran Simićc \\ ${ }^{1}$ Univerzitet u Kragujevcu, Prirodno-matematički fakultet, Institut za biologiju i \\ ekologiju, Kragujevac, Srbija \\ ${ }^{2}$ Univerzitet u Kragujevcu, Prirodno-matematički fakultet, Institut za hemiju, \\ Kragujevac, Srbija
}

\section{Rezime}

U remedijaciji zagađenih zemljišta sve češće se koriste drvenaste biljke. Analizirali smo sadržaj metala (Mn, Fe, Cu, Zn, Cr, Ca, Mg) u biljnim vrstama Populus nigra L. i Populus tremula L. i u zemljištu na kome rastu. Cilj istraživanja je da se, na osnovu sadržaja metala u biljnim organima (izdanci i lišće) i bioakumulacionog potencijala, utvrde razlike između ove dve vrste $\mathrm{i}$ ukaže na potencijalnu primenu ovih vrsta u fitoremedijaciji. Koristili smo atomsku apsorpcionu sprektrofotometriju za određivanje metala u zemljištu i biljnom materijalu. Rezultati su pokazali da je $P$. tremula bolji akumulator metala jer je usvojila veće količine $\mathrm{Mn}, \mathrm{Fe}, \mathrm{Cu}$ i $\mathrm{Zn}$ od $P$. nigra. $P$. nigra je usvojila više hroma u odnosu na $P$. tremula. Obe ispitivane biljne vrste su se pokazale kao dobri akumulatori cinka a bolji bioakumulacioni potenicijal je imala $P$. tremula od $P$. nigra iako je jasika imala jaku negativnu korelaciju prema Zn.

Ključne reči: $P$. nigra L., $P$. tremula L., fitoremedijacija, metali 